\title{
Role clarity as a Predictor of Nurses' Job Satisfaction
}

\author{
Fatma Rushdy Mohamed ${ }^{1}$ \& Eman Kamel Hosny ${ }^{2}$ \\ 1. Professor of Nursing Administration, Faculty of Nursing, Assiut University, Egypt. \\ 2. Lecturer of Nursing Administration, Faculty of Nursing, Assiut University, Egypt.
}

\begin{abstract}
Background: Job satisfaction affected positively by role clarity and in turn job satisfaction adds positive effect to nurse's roles and responsibilities. When employees and employers are satisfied with their jobs, this will make them committed to their organizations and in turn contributes to organizational success. Aims: To explore the relation between role clarity and job satisfaction among nurses and the relations between nurses' personal characteristics data, role clarity, and job satisfaction. Design: A descriptive correlational design was used. Subject and Method: The study was carried out at Medical and Surgical Departments at Assiut University Hospital, total number (141 nurse) (62) in Surgical and (79) in Medical. Using three tools, Personal characteristics data sheet, Role clarity questionnaire, and Job satisfaction questionnaire. Results: Causes of role ambiguity has the highest mean score (32.72 \pm 5.22$)$. Nurses perception about role clarity correlated positive with job satisfaction dimensions of communication and relations $\left(0.293^{* *}\right)$. Communication and relations correlated positive with educational qualification and marital status (0.020 and 0.005) respectively. Conclusions: Nurses are aware of causes of role ambiguity, and nurses' perception about role clarity correlated positive with job satisfaction dimension of communication and relations. Recommendations: During orientation period at the time of employment clearly define job description, job specification, and job classification that will reflect positive on their job satisfaction and general moral, and emphasis on educational preparation of diploma nurses with more courses and guidelines on how to understand their roles and responsibilities.
\end{abstract}

\section{Keywords: Role Clarity, Role ambiguity, Job Satisfaction \& Nurses.}

\section{Introduction}

Nurse satisfaction is considered as one indicator of the quality of health care services in the organization. Nurses' job satisfaction emphasize on personal feeling toward her own job. A nurse who is satisfied with her own job will add positive outcomes for organization (Robbins \& Judge, 2013). Role clarity adds significantly to the job satisfaction and in turn job satisfaction give positive effect for nurse's roles and responsibilities. Role clarity of the nurses has been present to increase the stability and perception of their job performance, increase psychological empowerment beside well performance (Rajaeipour \& Bahrami, 2008, Ify \& Rao, 2011, Gashtasb et al., 2013).

Role clarity is critical to representatives as it decides how well tasks are being processed and consequently the performance of an employees. Allemeh, et al., (2013), opines that nurses, who perceive their roles as obviously defined, know what is expected of them and are more suitable to render high quality services. On contrary, role ambiguity present when an employee's task or authority is not clearly defined and the employee becomes hesitated to do anything. It is appearing as the state where an employee does not take a clear guide about the expectation of his/her role in the job, and the requirement to accomplish their tasks (Panari et al., 2016, Rovithis, et al., 2017).
Logically, and based on two studies have documented role ambiguity as source of nurse's job dissatisfaction and if role ambiguity is diminished, this will led to increase job satisfaction level. It is important for the employer to clearly highlight the roles and responsibilities of their employees. What aspects are important, how they will be evaluated and how delivering the responsibilities of the roles will help the organizations achieve their goals and success (Rovithis, et al., 2017).

A survey conducted in 12 countries around the world by Aiken et al., (2012) demonstrated that most of nurses were dissatisfied with their jobs. It is observed that Netherlands had the lowest level of dissatisfaction (11\%) comparing with Greece dissatisfaction level was the highest (56\%), lower dissatisfaction among nurses in Netherlands back to better health care Management comparing with other countries. When health care managers hire their employees, attention must be paid first to setting role expectations for saving time and effort of both. When the employees know what is expected from their role, then they tend to perform better. The role clarity will improve job satisfaction and in turn their job performance. Having a structured role definition for their organization becomes very instrumental in improving the employee and organizational performance (Thangavelu \& Sudhahar, 2017). 


\section{Significance of study}

There are International studies done related to the study title as follows; the first one titled by "Role clarity, organizational commitment, and job satisfaction during Hospital reengineering' done by Kroposki, et al., (1999) and concluded that Participants who experienced much role conflict and ambiguity exhibited less organizational commitment and job satisfaction. Another study done by Mafuba, et al., (2015) titled by "Importance of role clarity: a critique of the literature", the study concluded that community learning disability nurses need a clear understanding of the concept of 'role'. This is important because it has implications for role clarity, role perception and role enactment when meeting the healthcare needs of people with learning disabilities. While there was a one national study done in upper Egypt by Abd Elhamid, et al., (2013) titled by" Role conflict, role ambiguity and nurses' performance at Minia University Hospital" , the study concluded that the majority of studied sample at Minia University Hospital have high level of role conflict and role ambiguity regardless of demographic characteristics. So, When each nurse understand clearly his/her role and causes of role ambiguity was discovered, this will affect positively on nurses' job satisfaction and in turn, job satisfaction adds positive effect to nurse's roles and responsibilities. There is a little studies discussed relation between role clarity and job satisfaction among nurses. so, the researchers conducted this study in an attempt to reduce many clashes occur among nurses in health care settings, caused by role ambiguity which make them dissatisfied with their jobs and in turn leads to shorten in the patients care.

\section{Aim of study}

To explore the relation between role clarity and nurses' job satisfaction.

\section{Research objectives}

1- Determine the level of role clarity among nurses

2- Detect the level of job satisfaction among nurses

3- Find out the relation between role clarity and job satisfaction among nurses

\section{Research questions}

What is the level of role clarity among nurses?

What is the level of job satisfaction among nurses?

Is there a relation between role clarity and nurses' job

satisfaction?

Is there a relation between role clarity and nurses' personal

characteristics data?

Is there a relation between nurses' job satisfaction and their persomal asked to fill them out and return them characteristics data?

\section{Subject \& Method}

Study design: A descriptive correlational design was used in the present study.

Setting: The study was carried out at Medical and Surgical Departments at Assiut University Hospital. aforementioned settings with a total number of 141 nurses which classified into (62) in the Surgical department and (79) in the Medical department.

\section{Data collection tools}

Three tools were used to collect data for this study as follows: $1^{\text {st }}$ tool: Personal characteristics data sheet including age, marital status, educational qualification, years of experience, and department. $2^{\text {nd }}$ tool: Role clarity questionnaire: which developed by El-sayed, (1997). It divided into two parts, $1^{\text {st }}$ one related to causes of role ambiguity which includes twenty-two statements with scoring system (yes=2) and $(n o=1)$ respectively. The $2^{\text {nd }}$ one is the nurses perception about role clarity included six statements with scoring system (disagree $=1)$, $($ Uncertain $=2$ ), and (Agree $=3$ ). $3^{\text {rd }}$ tool: Job satisfaction questionnaire: which developed by McConell, (1998) and adopted from Mohamed, (2002) which included four dimensions: first one; nature of work (4 items), second one; communication and relations (10 items), third one; policy and rules (6 items), and finally fourth one; work condition (1 item) with scoring system $\quad($ satisfied $=1), \quad($ Undecided $=2), \quad$ and (Dissatisfied =3). Cronbach's alpha coefficient method used to measuring internal consistency of the study tools, results were high, exceeding 0.80 .

Pilot study

A pilot study was fulfilled to test the questionnaire reliability, feasibility, and applicability. It was carried out on ten nurses excluded from the study sample of the inpatient Midwifery department. Data collected from the pilot study were analyzed. A pilot study has also served in estimating the time needed for filling the questionnaire, and it revealed that each questionnaire would take about 15-20 minutes for filling.

\section{Fieldwork}

Official permission was obtained from the Hospital Director, the Nursing Service Administration Director, and the Head of each department before embarking on the data collection. The actual data collection was started in November 2018 and ended in December 2018. The researchers met the eligible nurses, explained to them the purpose of the study, and asked them for their oral consent to participate. Those who agreed to participate were given the tools anonymously in the same setting or the next day.
Subject: The subject includes all nurses working in 


\section{Ethical Considerations}

The study proposal approved by Ethical Committee of Nursing Faculty - Assiut University. The participants' oral consent was obtained after informing them about their rights to participate, refuse, or withdraw at any time. Total confidentiality of any obtained information was ensured. The study maneuver could not entail any harmful effects on participants.

\section{Statistical Analysis}

Data entry and statistical analysis were done using SPSS 19.0 statistical software package. Data were presented using descriptive statistics in the form of frequency, percentages, mean and standard deviation Pearson correlation analysis was used for assessment of the inter-relationships among quantitative

\section{Results}

Table (1): Distribution of personal characteristics data for the studied nurses at Assiut University Hospital (no=141)

\begin{tabular}{|c|c|c|}
\hline \multirow{2}{*}{$\begin{array}{ll}\text { Personal characteristics data } \\
\text { Age: (years) }\end{array}$} & \multicolumn{2}{|c|}{ Nurses (n=141) No. \% } \\
\hline & & \\
\hline $20-<30$ yr. & 103 & 73.1 \\
\hline $30-<40$ yr. & 27 & 19.1 \\
\hline $41-<50$ yr. & 10 & 7.1 \\
\hline $50 \mathrm{yr}$. and more. & 1 & 0.7 \\
\hline \multicolumn{3}{|l|}{ Sex: } \\
\hline Male & 17 & 12.1 \\
\hline Female & 124 & 87.9 \\
\hline \multicolumn{3}{|l|}{ Educational qualification: } \\
\hline Secondary School of the Nursing Diploma. & 77 & 54.7 \\
\hline Technical Institute of Nursing. & 59 & 41.8 \\
\hline Bachelor Degree of Nursing. & 5 & 3.5 \\
\hline \multicolumn{3}{|l|}{ Marital status: } \\
\hline Single & 35 & 24.8 \\
\hline Married & 103 & 73.1 \\
\hline Divorced & 2 & 1.4 \\
\hline Widow & 1 & 0.7 \\
\hline \multicolumn{3}{|l|}{ Years of experience: } \\
\hline $1-<5$ yrs. & 34 & 23.9 \\
\hline $5-<10$ yrs. & 57 & 40.9 \\
\hline $10-<15$ yrs. & 31 & 21.8 \\
\hline $15 \mathrm{yrs}$ and more & 19 & 13.4 \\
\hline Mean \pm SD & \multicolumn{2}{|c|}{$2.23 \pm 0.96$} \\
\hline Department: & & \\
\hline Surgical & 62 & 44.0 \\
\hline Medical & 79 & 56.0 \\
\hline
\end{tabular}


Table (2): Distribution of role clarity items among the studied nurses at Assiut University Hospital (no=141)

\begin{tabular}{|c|c|c|c|c|c|c|}
\hline \multirow{2}{*}{ Role clarity items } & \multicolumn{2}{|c|}{ Disagree } & \multicolumn{2}{|c|}{ Not sure } & \multicolumn{2}{|c|}{ Agree } \\
\hline & No. & $\%$ & No. & $\%$ & No. & $\%$ \\
\hline - Know the limits of the authority that you own. & 28 & 19.9 & 59 & 41.8 & 54 & 38.3 \\
\hline - There are clear and planned goals for your job. & 30 & 21.3 & 56 & 39.7 & 55 & 39.0 \\
\hline - Know how to divide your time well. & 33 & 23.4 & 34 & 24.1 & 74 & $\mathbf{5 2 . 5}$ \\
\hline - Know what your responsibilities are well. & 28 & 19.9 & 47 & 33.3 & 66 & 46.8 \\
\hline - Know exactly what is expected of you. & 31 & 22.0 & 55 & 39.0 & 55 & 39.0 \\
\hline $\begin{array}{l}\text { - There are clear explanations and goals for what } \\
\text { is expected of you. }\end{array}$ & 40 & 28.4 & 53 & 37.6 & 48 & 34.0 \\
\hline
\end{tabular}

Table (3): Distribution of causes of role ambiguity among the studied nurses at Assiut University Hospital (no=141)

\begin{tabular}{|c|c|c|c|c|}
\hline \multirow{2}{*}{ Causes of role ambiguity } & \multicolumn{2}{|c|}{ Yes } & \multicolumn{2}{|c|}{ No } \\
\hline & No. & $\%$ & No. & $\%$ \\
\hline 1) Lack of clear expectations for the profession. & 67 & 47.5 & 74 & 52.5 \\
\hline 2) The regulations and rules that are found in the hospital are unclear. & 63 & 44.7 & 78 & 55.3 \\
\hline 3) My responsibilities are unlimited. & 51 & 36.2 & 90 & 63.8 \\
\hline 4) It is not known about the equipment and tools in the department. & 23 & 16.3 & 118 & 83.7 \\
\hline 5) There is not enough time to adapt to the new responsibilities. & 53 & 37.6 & 88 & 62.4 \\
\hline 6) Lack of clarity of the work goals and duties to be performed. & 56 & 39.7 & 85 & 60.3 \\
\hline 7) Understanding the nurse / nurse of her role differs from your actual role. & 57 & 40.4 & 84 & 59.6 \\
\hline $\begin{array}{l}\text { 8) Not sure of my role so that there is more than one person who sets goals } \\
\text { and expectations for performance. }\end{array}$ & 59 & 41.8 & 82 & 58.2 \\
\hline $\begin{array}{l}\text { 9) Lack of information available about my duties and powers and the way } \\
\text { in which a performance evaluation is carried out. }\end{array}$ & 55 & 39.0 & 86 & 61.0 \\
\hline $\begin{array}{l}\text { 10) Lack of clear instructions, directions or documents to guide the } \\
\text { performance. }\end{array}$ & 64 & 45.4 & 77 & 54.6 \\
\hline 11)Supervisors do not accept ideas that conflict with their personal interests. & 85 & 60.3 & 56 & 39.7 \\
\hline 12)Doctors underestimate nurses. & 84 & 59.6 & 57 & 40.4 \\
\hline 13)Lack of cooperation among members of the nursing team. & 69 & 48.9 & 72 & 51.1 \\
\hline 14)The small number of members of the nursing team. & 102 & 72.3 & 39 & 27.7 \\
\hline 15)The hospital does not provide nurses with appropriate training courses. & 85 & 60.3 & 56 & 39.7 \\
\hline 16)He had to leave my sick son at home in order to go to work. & 77 & 54.6 & 64 & 45.4 \\
\hline 17)Workplace congestion. & 79 & 56.0 & 62 & 44.0 \\
\hline $\begin{array}{l}\text { 18) The nurses do not prepare for sudden changes in work, which makes } \\
\text { them less resistant and more vulnerable to conflict. }\end{array}$ & 62 & 44.0 & 79 & 56.0 \\
\hline $\begin{array}{l}\text { 19) The nurse is not aware of the situation, which makes her unable to } \\
\text { control the situation. }\end{array}$ & 49 & 34.7 & 92 & 65.2 \\
\hline 20)My personal goals conflict with the goals of the institution. & 57 & 40.4 & 84 & 56.6 \\
\hline 21)There is an inconsistency between the tasks to be accomplished. & 78 & 55.3 & 63 & 44.7 \\
\hline 22) The presence of more than one controlling authority in the hospital. & 103 & 73.1 & 38 & 27.0 \\
\hline
\end{tabular}


Table (4): Mean scores of role clarity factors and job satisfaction dimensions among the studied nurses at Assiut University Hospital (no=141).

\begin{tabular}{|l|c|}
\hline \multicolumn{1}{|c|}{ Role clarity factors } & Nurses \\
\cline { 2 - 2 } & Mean \pm SD \\
\hline Causes of role ambiguity & $32.72 \pm 5.22$ \\
\hline Nurses perception about role clarity & $13.14 \pm 3.18$ \\
\hline Job satisfaction dimensions & \\
\hline Nature of work & $8.61 \pm 8.62$ \\
\hline Communication and relations & $23.69 \pm 4.31$ \\
\hline Policy and rules & $14.02 \pm 4.05$ \\
\hline Work condition & $2.53 \pm 0.80$ \\
\hline
\end{tabular}

Table (5): Correlation between the job satisfaction dimensions and role clarity scores among studied nurses at Assiut University Hospital (no=141)

\begin{tabular}{|l|c|c|c|c|}
\hline \multirow{2}{*}{ Role Clarity Factors Scores } & \multicolumn{3}{|c|}{ Job Satisfaction Factors Scores } \\
\cline { 2 - 5 } & Nature of work & $\begin{array}{c}\text { Communication and } \\
\text { relations }\end{array}$ & $\begin{array}{c}\text { Policy and } \\
\text { rules }\end{array}$ & $\begin{array}{c}\text { Work } \\
\text { condition }\end{array}$ \\
\hline Causes of role ambiguity & 0.089 & $0.036^{* *}$ & $0.476^{* *}$ & $0.476^{* *}$ \\
\hline $\begin{array}{l}\text { Nurses perception about role } \\
\text { clarity }\end{array}$ & 0.159 & $0.293^{* *}$ & 0.107 & 0.116 \\
\hline
\end{tabular}

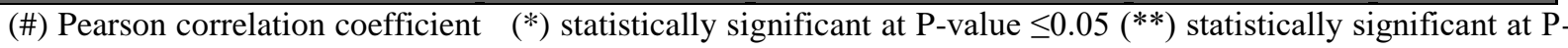
value $\leq 0.001$

Table (6): Correlation between the scores of role clarity and nurses' personal characteristics data at Assiut University Hospital (no=141)

(\#) Pearson correlation coefficient

\begin{tabular}{|l|c|c|}
\hline \multirow{2}{*}{ Personal Characteristics } & \multicolumn{2}{|c|}{ Role Clarity } \\
\cline { 2 - 3 } & $\begin{array}{c}\text { Causes of role } \\
\text { Ambiguity }\end{array}$ & $\begin{array}{c}\text { Nurses perception } \\
\text { about role clarity }\end{array}$ \\
\hline Age $\#)$ & -0.112 & -0.022 \\
\hline Sex & 0.102 & -0.093 \\
\hline Marital status & -0.035 & -0.165 \\
\hline Educational Qualification & 0.079 & -0.013 \\
\hline Years of experience & -0.040 & -0.096 \\
\hline
\end{tabular}

Table (7): Correlation between the scores of job satisfaction dimensions and nurses' personal characteristics data at Assiut University Hospital (no=141)

\begin{tabular}{|l|c|c|c|c|}
\hline \multirow{2}{*}{ Personal Characteristics } & \multicolumn{4}{|c|}{ Job Satisfaction Factors Scores } \\
\cline { 2 - 5 } & $\begin{array}{c}\text { Nature of } \\
\text { Work }\end{array}$ & $\begin{array}{c}\text { Communication and } \\
\text { relations }\end{array}$ & $\begin{array}{c}\text { Policy and } \\
\text { Rules }\end{array}$ & $\begin{array}{c}\text { Work } \\
\text { condition }\end{array}$ \\
\hline Age & 0.020 & 0.128 & 0.143 & 0.028 \\
\hline Sex & $0.200^{*}$ & 0.057 & 0.094 & 0.028 \\
\hline Marital status & 0.087 & 0.005 & 0.040 & 0.006 \\
\hline Educational Qualification & 0.075 & 0.020 & 0.074 & 0.118 \\
\hline Years of experience & 0.030 & 0.053 & 0.075 & 0.131 \\
\hline
\end{tabular}

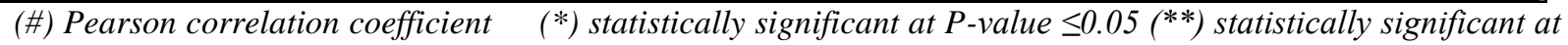
$P$-value $\leq 0.001$ 
Table (1): Distribution of personal characteristics data of the studied nurses. Data in this table illustrates that nearly to three quarters of studied nurses $(73.1 \%)$ were aged between 20-30 years old and they are married, the majority of them were females $(87.9 \%)$, More than half of them graduated from secondary school of nursing diploma $(54.7 \%),(40.9 \%)$ of them have experience between 6-10 years, and more than half of them $(56.0 \%)$ working at Medical department. Table (2): Distribution of role clarity items among the studied nurses at Assiut University Hospital

Data in this table shows that from more than one third to more than half of the studied nurses agree on the items of role clarity as follows; know how to divide your time well, know what your responsibilities are well, there are clear and planned goals for your job, and know exactly what is expected of you $(52.5 \%$, $46.8 \%, 39.0 \%, 39.0 \%$ ) respectively.

Table (3): Distribution of causes of role ambiguity among the studied nurses at Assiut University Hospital Displays that majority of studied nurses' mention that it is known about the equipment and tools in the department $(83.7 \%)$, and $(60.3 \%)$ mention that supervisors do not accept ideas that conflict with their personal interests \& the hospital does not provide nurses with appropriate training courses.

Table (4): Mean scores of role clarity factors and job satisfaction dimensions of the studied nurses at Assist University Hospital. As regarding to role clarity factors, highest mean is recorded in causes of role ambiguity (32.72 \pm 5.22$)$. As regarding to job satisfaction factors, highest mean is recorded in communication and relations $(23.69 \pm 4.31)$ followed by Policy and rules $(14.02 \pm 4.05)$ as revealed in table (4).

Table (5): Correlation between role clarity factors and job satisfaction dimensions. shows presence of strong significant correlation between nurses perception about role clarity factor and communication and relations $\left(0.293^{* *}\right)$. There is a strong significant correlation between causes of role ambiguity and communication and relations, policy and rules, and work condition $\left(-0.0369 * *,-0.476^{* *}\right.$, $\left.0.476^{* *}\right)$ respectively.

Table (6): Correlation between role clarity factors and nurses' personal characteristics data. Causes of role ambiguity factor is correlated positive with sex and educational qualification (0.102 and0.079), except that the two variables of role clarity factors correlated negative with all nurses' personal characteristics data, as illustrated in table (6).

Table (7): Correlation between job satisfaction dimensions and nurses' personal characteristics data. Reveals that there are negative correlations between the nature of work and age, sex and marital status
$(-0.020,-0.200 *$ and -0.087$)$ except with educational qualification and years of experience is correlated positively (0.075 and 0.030). Also, there are negative correlations between Communication and relations with age, sex and years of experience $(-0.128,-0.057$, and -0.053) except marital status and educational qualification (0.005, and 0.020). Policy and rules correlated negatively with all personal characteristics variables, contrary to work condition that correlated positively with all personal characteristics data except with educational qualification $(-0.118)$.

\section{Discussion}

Job satisfaction defined by Liu et al., (2012) as all the feelings that an individual has about his/her job. Regarding to job satisfaction dimensions, Results of the current study revealed that high mean score in job satisfaction factors is related to communication and relations followed by policy and rules. This means that nurses are satisfied mostly with communication and relation between them and other health care individuals, then they are satisfied with policy and rules that determine the boundaries they follow in their work and as a guide for them. This is may be also, related to that nurses are satisfied because they are afforded a greater ability to manage work and personal responsibilities during traditional work hours (Caillier, 2012). Also, may be that they have a greater sense of autonomy (Golden, 2009), which is viewed as a powerful antecedent of job satisfaction, a positive association between communication and job satisfaction among nurses as revealed in the study conducted by Vermeir et al., (2017) titled job Satisfaction in relation to communication in Health Care among nurses.

From another perspective, studied nurses are least satisfied with the work condition which has the lowest mean score. This results in line with Teems et al., (2017) whose conducted research on emergency nurses department, found that most respondents were satisfied with the work-itself and work relationships and least satisfied with current work conditions.

Regarding to role clarity items, The main result of this study focused on that causes of role ambiguity the majority of studied nurses mention that it is known about the equipment and tools in the department, and mention that supervisors do not accept ideas that conflict with their personal interests $\&$ The hospital does not provide nurses with appropriate training courses with a high mean scores for nurses and as regard to perception about role clarity the highest percentage were more than one third to more than half of the studied nurses agree on the items of role clarity as follows; know how to divide your time well, know what your responsibilities are well, there are clear and planned 
goals for your job, and know exactly what is expected of you with a lowest mean score. This indicated that nurses understand well and they are aware of causes that lead to role ambiguity especially when it comes to criteria for performance evaluation and authority on the job. Role ambiguity defined by Zhao \& Rashid, (2010) the missing of satisfactory information which is required for person in order to accomplish his role in a satisfactory way. Rovithis et al., (2017) in their study titled by role conflict and ambiguity among physicians and nurses in the public health care sector in Crete, the result appear ambiguity is the higher mean score among nurses.

Also the results of current study reveals, causes of role ambiguity correlated positive with sex and educational qualification of studied nurses. This means that level of education affects nurses' knowledge of the reasons for the role's ambiguity. In the current study, most of the studied nurses are female with diploma qualification.

When an employee does not equipped with enough information to complete his/her required duties, he/she experience role ambiguity; if tasks are not clear or even ambiguous, it can lead to low job satisfaction (Tarrant \& Sabo, 2010).

Regarding to relation between role clarity and job satisfaction in the current study, there were a strong significant correlation was present between nurses' perception about role clarity with communication, and relations. This explains that the nurses understand the importance of communication and relations with others for the better understanding of their responsibilities, this is in line with the findings of Koustelios et al., (2016). Those studies concluded that role clarity is a significant predictor of job satisfaction. From researcher point of view, role to be clear for nurses must be clear firstly for first line nurse managers and supervisors whom are responsible for them; when they know their job limits and their jurisdictional boundaries, they can distribute responsibilities and tasks on their staff fairly with clear expectations; this is what make nurses be clear about their jobs. Abed \& Aly, (2016) found a significant correlation between employees' job satisfaction and the clarity of their job expectations, feedback provisions and accuracy of performance rating.

In other hand, there were strong significant negative correlations between causes of role ambiguity and communication and relations, policy and rules, and work condition. Individuals that have more freedom over their work and more to say about what to do experience more role clarity than those who do not, that can hinder the negative impact on job satisfaction (Belias et al., 2015). From researcher point of view, nurses' knowledge about causes of role ambiguity restricted by many factors that may be related to rigidity of policy and rules, work condition itself, and nature of communications between nurses and responsible people in the organization.

Employees are more satisfied with their job when they are supported from their co-workers and superiors, have a clear understanding of the extent of their job roles, have superiors that are willing to help them and influence them in a good way, and are informed of important decision making within the company. Nyanga et al., (2012) identify that low job satisfaction perceived as one of the consequences of role ambiguity.

It is observed that there is a positive correlation between educational qualification either with communication and relation or causes of role ambiguity. This is refers to education level nurses have and educational programs they received in their work effect directly on to what extent nurses' knowing and understanding about causes of role ambiguity, also effect on level of communication and relations between other health care personnel at all levels. Rizany et al., (2019) express that educational level is the educational degree of nurses to act in a health care organizations, experts also described that nurses' satisfaction were affected by personal characteristics such as age, sex, education level, and working experience.

In general the current study results in line with previous studies who concluded that job satisfaction of nursing personnel at all levels affected by role ambiguity, by other meaning when employees' job roles are not clear they are more likely to be dissatisfied with their jobs, therefore clear roles are important for well-being, performance and could possibly improve some satisfaction among employees (Piko, 2006, Wu \& Norman, 2006, Tarrant \& Sabo, 2010). Yukl, (2010) noted that even highly competent and motivated employees may fail to achieve a high level of performance if they are unsure about their work goals and responsibilities. Two studies on healthcare providers emphasized on, inconsistencies in role expectations can lead to inadequacy in performance and discourage nurses from achieving hospital goals (Lambert \& Lambert, 2001, Smith, 2011).

\section{Conclusion}

As related to this study role clarity significant for nurses' job satisfaction. Nurses are aware of causes of role ambiguity, and nurses' perception about role clarity correlated positive with job satisfaction dimension of communication and relations. In addition to educational qualification correlated positive with causes of role ambiguity and with communication and relations. 


\section{Recommendations}

According to the study results the following recommendations are suggested:

- Emphasis on educational preparation of diploma nurses with more courses and guidelines on how to understand their roles and responsibilities.

- During orientation period at the time of employment clearly define job description, job specification, and job classification that will reflect positive on their job satisfaction and general moral.

- Managers can reduce role ambiguity by setting specific task objectives, communicating clearly about performance expectations, and providing clear direction about how to accomplish work activities.

- Regular meeting should done by the charge nurse to keep subordinates informed about changes in the organizational environment that may have an impact on their work and providing them with periodic feedback about their performance.

\section{References}

1. Abd Elhamid, E., Mohamed, F., Abood, S., (2013): Role conflict, role ambiguity and nurses' performance at Minia University Hospital, Assiut Scientific Nursing Journal, 1(1), Pp. 37-51.

2. Abed, F., \& Aly, S., (2016): The relationship between quality of performance appraisal process and nurses job satisfaction as perceived by staff nurses at selected hospitals. International Journal of Nursing Didatics. doi: http://dx.doi.org/10.15520/ijnd.2016.vol6.iss1 2.178

3. Aiken, L., Sermeus, W., Van den Heede, K., Sloane, D., Busse, R., McKee, M., \& Kutney-Lee, A., (2012): Patient safety, satisfaction, and quality of hospital care: Cross sectional surveys of nurses and patients in 12 countries in Europe and the United States. British Medical Journal, 344, Article e1717. doi:10.1136/bmj.e1717

4. Allemeh, S., Harooni, A., Chaleshtari, M., \& Asadi, A., (2013): Investigating the Relationship between Variables and Role Clarity effects on the Perceived Service Quality of Front Line Employees. International Journal of cademic Research in Business and Social Sciences. 3(5), $121-138$.

5. Bass, B., (1990): From transaction to transformational leadership: Learning to share the vision. Organisational Dynamics. 2 (4), 19- 31.cited in (Role clarity, Self-Concept and Job Satisfaction of Library Personnel in Selected University Libraries in Ogun State, Nigeria Onuoha, Uloma Doris1, Ogunjinmi, Tolulope2 and Owodunni, Mayedun3. Journal of Applied Information Science and Technology, 9 (2) (2016) pp: 9-16).

6. Koustelios, A., Belias, D., Sdrolias, L., \& Aspridis, G., (2016): Job Satisfaction, role conflict and autonomy of employees in the Greek banking organization. Procedia - Social and Behavioral Sciences, 175, 324-333. doi:10.1016/j.sbspro.2015.01.1207).

7. Caillier, J., (2012): The impact of teleworking on work motivation in a U.S. federal government agency. American Review of Public Administration, 42(4), 461-480.

8. El-sayed, K., (1997): Relationship between perceived role conflict and role ambiguity with stress level among new Baccalaureate Nursing Student and Intern in Tanta University, Unpublished Master Degree thesis.

9. Gashtasb A., Ali Y., Mohammadbagher F., \& Ghasem S., (2013): The Relationship between Role Clarity and Job Compatibility in the Sport and Physical Education Office. International Journal of Sport Studies, Vol., 3 (2), 194-198

10. Golden, T., (2009): Applying technology to work: Toward a better understanding of telework. Organizational Management Journal, $6,241-250$

11. Ify Diala \& Rao Nemani (2011): Job Satisfaction: Key Factors influencing Information Technology (IT) professionals in Washington DC. International Journal of Computer Technology and Applications, 2 (4), 827-838

12. Kelly, B., (1996): Hospital nursing. 'It's a battle!' A follow-up study of English graduate nurses. J Adv Nurse; 24: 1063-9.

13. Kroposki , M., Murdaugh, C., Tavakoli, A., Parsons, M., (1999): Role clarity, organizational commitment, and job satisfaction during Hospital reengineering;12(1), Pp. 27-34.

14. Lambert, V., \& Lambert, C., (2001): Literature review or role stress/ strain on nurses: an international perspective. Nurs Health Sc.; 3(3), 161-72.

15. Liu, C., Zhang, L., Ye, W., Zhu, J., Cao, J., Lu, X., \& Li, F., (2012): Job satisfaction and intention to leave: A questionnaire survey of hospital nurses in Shanghai of China. Journal of Clinical Nursing, 21, 255-263. doi: 10.1111/j.1365- 2702.2011.03766.x 
16. Mafuba, K., Kupara, D., Cozens, M., \& Kudita, C., (2015): Importance of role clarity: a critique of the literature, Downloaded from RCNi.com

17. https://www.researchgate.net/publication/2824 31757_Importance_of_role_clarity_a_critique _of_the_literature.

18. McConnel, E. (1998): the coalescence of technology and humanism in nursing practice: it doesn't just happen and doesn't come easily. Holistic nursing practice, www.elibrary.com/getdocigi?id=119

19. Michelle, T., \& Erin, H., (2017): An Investigation of Job Satisfaction among Nurses in the Emergency department.

20. Mohamed, F. (2002): The relationship between absenteeism and job satisfaction among nurses at Assiut University Hospital, Unpublished Master Degree thesis.

21. Nyanga T., Mudhovozi P., \& Regis C. (2012): Causes and Effects of Role Ambiguity as Perceived by Human Resource Management Professionals in Zimbabwe Journal of social scince, Volume 30, Issue 3 , Pages 293-303 | Published online: 09 Oct 2017.Of Nursing Didatics. doi: http://dx.doi.org/10.15520/ijnd.2016.vol6.iss1 2.178

22. Panari1; Levati; Bonini; Tonelli; Alfieri; and Artioli, (2016): The ambiguous role of healthcare providers: a new perspective in Human Resources Management. Journal of Health care professionals Acta Biomed for Health Professions Vol. 87, S. 2: Pp: 49-60

23. Piko, B. (2006): Burnout, role conflict, job satisfaction and psychosocial health among Hungarian health care staff: A questionnaire survey. International Journal of Nursing Studies, $\quad 43(3), \quad 311-318$. doi:10.1016/j.ijnurstu.2005.05.003

24. Rajaeipour; Hassan, Bahrami, \& Susan. (2008): The relationship between role clarity and job commitment of the employees of the schools of Isfahan University of Medical Sciences. Shahrekord University of Medical Sciences Journal, 10(2), 30-36

25. Rizany, I., Hariyati, T., Afifah, E., \& Rusdiyansyah, (2019): The Impact of Nurse Scheduling Management on Nurses' Job Satisfaction in Army Hospital: A CrossSectional Research. SAGE Open. DOI: 10.1177/2158244019856189 journals.sagepub.com/home/sgo.

26. Robbins, S., \& Judge, T., (2013): Organizational behavior, $15^{\text {th }}$ ed., Upper Saddle River, NJ: Pearson Education.
27. Rovithis, L., Rikos, M., and Patiraki, P. (2017): Role conflict and ambiguity among physicians and nurses in the public health care sector in Crete, original paper archives of hellenic medicine, 34(5):648-655

28. Shahidul, H. (2013): Public Administration Review, Vol. 73, Iss. 5, pp. 716-725. The American Society for Public Administration. DOI: 10.1111/puar.12100.

29. Smith, A. (2011): Role Ambiguity and Role Conflict in Nurse Case Managers: An Integrative Review. Professional Case Manager; 16(4): 182-96.

30. Tarrant, T., \& Sabo, C., (2010): Role conflict, role ambiguity, and job satisfaction in nurse executives. Nursing Administration Quarterly, 34(1), 72-82. doi:10.1097/NAQ.0b01 3e3181c95eb5

31. Teems M., Helbing E., \& RN, BSN (2017): An Investigation of Job Satisfaction among Nurses in the Emergency department. International Journal of Nursing Studies, 43(3), 311-318. doi:10.1016/j.ijnurstu.2005.05.003

32. Thangavelu A., \& Sudhahar C., (2017): Role Clarity and Job Performance among the Employees in Small and Medium IT Industries, Research on Humanities and Social Sciences www.iiste.org Vol.7, No.17, 2017 Special Issue - Organized by Department of Social Work, Bishop Heber College ISSN 2224-5766 (Paper) ISSN 2225-0484 (Online)

33. Vermeir, P., Degroote, S., Vandijck, D., \& Vogelaers, D., (2017): Job Satisfaction in Relation to Communication in Health Care among Nurses: A Narrative Review and practical Recommendations. SAGE Open 7(2) DOI: $10.1177 / 2158244017711486$

34. Wu, L., \& Norman, I., (2006): An investigation of job satisfaction, organizational commitment and role conflict and ambiguity in a sample of Chinese undergraduate nursing students. Nurse Education Today, 26(4), 304314. doi:10.1016/j.nedt.2005.10.011.

35. Yukl, G., (2010): Leadership in Organizations. $7^{\text {th }}$ ed. Upper Saddle River, NJ: Prentice Hall.

36. Zhao, L., \& Rashid, H., (2010): The mediating role of work-leisure conflict on job stress and retention of IT professionals. J Manage Inform Dec Sci., 13:25 